\title{
Ageing-Time Dependent Changes of Angiotensin I-Converting Enzyme-Inhibiting Activity of Protein Hydrolysates Obtained from Dry-Cured Pork Loins Inoculated with Probiotic Lactic Acid Bacteria
}

\author{
Paulina Kęska $^{1} \cdot$ Joanna Stadnik ${ }^{1}$ i
}

Accepted: 17 September 2018 / Published online: 24 September 2018

(c) The Author(s) 2018

\begin{abstract}
This study aimed to determine the ageing-time dependent changes of the angiotensin I-converting enzyme (ACE)-inhibition of protein extracts obtained from LAB-inoculated dry-cured pork loins over 360 days of ageing and their hydrolysates obtained after in vitro hydrolysis and absorption. The increasing ageing time was accompanied by a growth in the ACE inhibitory activity of the water-soluble and salt-soluble protein extracts. Based on the hierarchical cluster analysis, 180 days was indicated as the optimal time for ageing of dry-cured pork loins in terms of ACE inhibition. The effect of the strain used on the ACE inhibition varied over long-term aging. The peptides generated during in vitro hydrolysis have between 6 and 22 amino acids in a sequence; the Pro, Ala, Lys, and Glu molecules comprise the largest share. This study demonstrated that pork muscle proteins may lead to production of numerous peptides with ACE inhibitory properties.
\end{abstract}

Keywords ACE inhibiting peptides $\cdot$ Dry-cured products $\cdot$ Meat $\cdot$ Gastrointestinal hydrolysis

\section{Introduction}

Hypertension (HT) or high blood pressure (HBP), defined as the long-term elevation of blood pressure (BP) over $140 / 90 \mathrm{mmHg}$ (systolic/diastolic), is a leading cause of cardiovascular mortality as identified by the World Health Organization (Chockalingam 2008). In a healthy human being, the renin-angiotensin-aldosterone system (RAAS) in plasma is primarily responsible for maintaining normal blood pressure. Its stimulation by low blood pressure or nerve impulses (e.g., in stressful situations) causes the kidneys to release the enzyme renin. The release of renin into the bloodstream results in the cleavage of angiotensin I from angiotensinogen (prohormone), which in turn is converted into the angiotensin II (vasoconstrictor) by ACE. ACE is a dipeptidyl carboxypeptidase (EC 3.4.15.1), which catalyzes the conversion of angiotensin I (decapeptide) to angiotensin

Joanna Stadnik

joanna.stadnik@up.lublin.pl

1 Department of Animal Raw Materials Technology, Faculty of Food Science and Biotechnology, University of Life Sciences in Lublin, Skromna 8, 20-704 Lublin, Poland
II (octapeptide) via the cleavage of the C-terminal dipeptide His-Leu. The other function of ACE is catalyzing bradykinin (a known vasodilator) degradation (Gallego et al. 2017; Wu et al. 2017).

One of the approaches used in medicine to lower BP in HT is to interrupt the action of ACE by ACE inhibitors (Iwaniak et al. 2014). Numerous synthetic ACE inhibitors are commercially available; however, nutritionists claim that the ACE inhibitory peptides obtained in food are promising supportive agents in the therapy when combined with drugs and can be used to treat and prevent HT. Regardless of lower ACE inhibitory activity in vitro, ACE inhibitory peptides do not have any harmful side effects, such as angioedema and dry cough, which are usually associated with synthetic ACE inhibitory drugs (Hong et al. 2008; Vermeirssen et al. 2004). ACE inhibitors are the most frequently studied food peptides. These peptides are known to act on humans and spontaneously hypertensive rats (SHR) and have been found in fish, eggs, milk, and plants (Iwaniak et al. 2014). However, minimal information exists on ACE inhibitory peptides obtained from meat. Arihara et al. (2001) first identified two ACE-inhibitory pentapeptides (MNPPK and ITTNP), named myopentapeptides (A and B), corresponding to position 
79-83 and 306-310 on the myosin heavy chain, respectively; both peptides were derived from porcine skeletal muscle proteins. Antihypertensive activity of these myopentapeptides in SHR were demonstrated in in vivo studies by Nakashima et al. (2002). Katayama et al. (2007) generated ACE inhibitory octapeptide (VKKVLGNP) by enabling digestion of the crude myosin light chain with pepsin. Another myosinderived peptide was identified by Muguruma et al. (2009) in a pepsin hydrolysate of porcine myosin B.

Our in silico analysis have also shown that porcine myofibrillar proteins offer considerable potential as a novel source of bioactive peptides that are ACE inhibitors (Kęska and Stadnik 2016). Proteolytic degradation of meat proteins is an important process that occurs during the processing of meat into cured ham or fermented sausages. In these products, ACE inhibitory peptides are released due to the action of endogenous muscle peptidases (Arihara 2006). Use of the term ACE inhibitor or antihypertensive peptide must be preceded by a study confirming the in vitro and/or in vivo activity of the peptide (Iwaniak et al. 2014). Scientists demonstrated that ACE inhibitory peptides derived from Spanish dry cured ham were highly stable against simulated in vitro digestion with gastrointestinal proteases (Escudero et al. 2014). The in vivo antihypertensive activity of the drycured ham peptide AAATP has also been documented in animal hypertension models as it could effectively reduce decreased systolic blood pressure in SHR (Escudero et al. 2013). Dry-cured meat products as a natural source of antihypertensive peptides are particularly interesting because these peptides could counteract the adverse action of the product's $\mathrm{NaCl}$ content, which maintains a satisfactory BP (Stadnik and Kęska 2015). In addition to the action of endogenous muscle peptidases, the proteolytic system of applied starter cultures, mainly lactic acid bacteria (LAB), also participate in the generation of bioactive peptides from meat proteins (Mora et al. 2013; Pessione and Cirrincione 2016). Recent studies that included the use of LAB strains that have probiotic properties, such as Bifidobacterium animalis spp. lactis BB12, Lactobacillus rhamnosus LOCK900, and a potentially probiotic strain Lactobacillus acidophilus Bauer $€ 0938$ have demonstrated that apart from the health benefits resulting from its probiotic character, the gastrointestinal hydrolysis of LAB-inoculated dry-cured pork loins may yield several peptides with antiradical properties (Kęska and Stadnik 2018). However, to the best of our knowledge, no study has been focused on the ACE inhibitory activity of peptides obtained from LAB-inoculated dry-cured pork loins. Moreover, little information is available on the stability of the ACE inhibitory activity under varied time and hydrolysis conditions.

The objective of this study was to evaluate the stability of ACE inhibitory activity of protein extracts obtained from LAB-inoculated dry-cured pork loins over 360 days of ageing and the hydrolysates obtained after in vitro hydrolysis and absorption.

\section{Materials and Methods}

\section{Preparation of Dry-Cured Loins}

The experimental materials comprised 12 samples of $m$. longissimus thoracis collected at $24 \mathrm{~h}$ post mortem from half carcasses of Polish White Large fatteners that had a live weight of $120-130 \mathrm{~kg}$. At $48 \mathrm{~h}$ post-mortem, all the samples were cured with a mixture of $9.7 \mathrm{~g}$ curing salt, $0.3 \mathrm{~g}$ of $\mathrm{NaNO}_{3}$ per $\mathrm{kg}$, and $20 \mathrm{~g}$ sea salt. Then, the samples were maintained at $4{ }^{\circ} \mathrm{C}$ for $24 \mathrm{~h}$ to allow diffusion of the curing salt. After curing, samples were randomly divided into four experimental groups, with three samples per group. One of the groups $(\mathrm{C})$ was not treated further, while the three other groups were each inoculated with L. rhamnosus LOCK900 (LOCK), L. acidophilus Bauer Ł0938 (BAUER), and B. animalis ssp. lactis BB-12 (BB12), respectively; an initial level of $10^{6}-10^{7} \mathrm{CFU} / \mathrm{g}$ of meat was aimed at. Two of the strains: L. rhamnosus LOCK900 (Patent claim No. P-382760) from the Technical University of Łódź (Poland) and B. animalis subsp. lactis BB12 from the Christian Hansen collection (strain deposit number: DSM15954) fulfilled the required criteria for probiotic strains. The potentially probiotic strain L. acidophilus Bauer $€ 0938$ was obtained from the Technical University of Łódź (Poland). The inocula were prepared according to the procedure previously described by Wójciak et al. (2012) at the Department of Food Hygiene and Quality Management (Warsaw University of Life SciencesSGGW, Warsaw, Poland). After this, the loins were hung in a disinfected laboratory ageing chamber at a temperature of $16 \pm 1{ }^{\circ} \mathrm{C}$ and a relative humidity of $75-80 \%$ for 14 days. The, the loin pieces were vacuum-packed in PA/PE $(80 \mu \mathrm{m}$ thick) bags (Wispak, Lublin, Poland) and aged at $4 \pm 1{ }^{\circ} \mathrm{C}$ for 12 months. We performed three independent experimental trials. After 90, 180, 270, and 360 days of ageing, samples were collected for analyses. At each sampling, meat proteins were extracted using the method of Molina and Toldra (1992), with the modifications suggested by Fadda et al. (1999), to obtain water-soluble (WSF) and salt-soluble (SSF) fractions. The protein concentration of both fractions was obtained using the Biuret method (Gornall et al. 1949) using Liquick Cor-TOTAL PROTEIN 60 kit (Cormay Group, Łomianki, Poland).

\section{Simulated Gastrointestinal Hydrolysis and Absorption}

WSF and SSF were subjected to in vitro hydrolysis using pepsin and pancreatin according to Escudero et al. (2014). 
First, as a gastric hydrolysis phase, the protein fractions were adjusted to a pH of 2.0 with $1 \mathrm{M} \mathrm{HCl}$. A $6 \mathrm{M} \mathrm{HCl}(\mathrm{pH}$ 2.0) pepsin solution was added to protein fractions at ratio of 1:100, enzyme to substrate. The hydrolysis process was performed for $2 \mathrm{~h}$ at $37^{\circ} \mathrm{C}$ in darkness and with continuous stirring, after which the solution was neutralized to $\mathrm{pH} 7.0$ with $1 \mathrm{M} \mathrm{NaOH}$ to enable enzyme inactivation. Next, pancreatin was added at a ratio of 1:50, enzyme to substrate, for simulated intestinal hydrolysis (intestinal hydrolysis steps; at $37^{\circ} \mathrm{C}$ for $3 \mathrm{~h}$ in darkness with continuous stirring). Incubation was carried out for $3 \mathrm{~h}$ at $37{ }^{\circ} \mathrm{C}$ in the dark with continuous stirring. The enzyme was inactivated through heating at $95^{\circ} \mathrm{C}$ for $10 \mathrm{~min}$. Then, hydrolysates were dialyzed by using membrane tubes ( $7 \mathrm{kDa}$ molecular weight cut-off, Spectra/ Por $^{\circledR}$ ) against phosphate buffered saline (PBS; pH 7.4; 1:4, $\mathrm{v} / \mathrm{v}$ ) for $1 \mathrm{~h}$ at $37^{\circ} \mathrm{C}$ without light as a simulated absorption step. The products of protein degradation were determined after each gastrointestinal hydrolysis and absorption step by measuring the contents of the primary amino groups $\left(-\mathrm{NH}_{2}\right)$ via the trinitrobenzene sulfonic acid (TNBS) method (AdlerNissen 1979). The degradation products were expressed as $\mathrm{mg} / \mathrm{mL}$ of L-leucine amino equivalent, based on the curve of calibration.

\section{Determining ACE Inhibitory Activity}

ACE inhibitory activity was evaluated with $5 \mathrm{mM}$ of hippuryl-L-histidyl-L-leucine (HHL) as a substrate, using the spectrophotometric method described by Nasri et al. (2013). This method involves calculating the quantity of hippuric acid (HA) released from HHL during incubation with ACE in the presence or absence of the sample. A volume of $80 \mu \mathrm{L}$ of sample $(1 \mathrm{mg} / \mathrm{mL})$ was added to $200 \mu \mathrm{L}$ of $5 \mathrm{mM} \mathrm{HHL}$, and then preincubated at $37^{\circ} \mathrm{C}$ for $3 \mathrm{~min}$. HHL was prepared

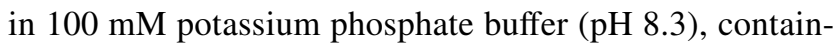
ing $300 \mathrm{mM} \mathrm{NaCl}$. The reaction was then initiated by adding $20 \mu \mathrm{L}$ of $0.1 \mathrm{U} / \mathrm{mL}$ ACE obtained from rabbit lung and prepared in the same buffer. The incubation was carried out at $37^{\circ} \mathrm{C}$ for $30 \mathrm{~min}$ with continuous agitation. The enzymatic reaction was halted by adding $250 \mu \mathrm{L}$ of $1 \mathrm{M} \mathrm{HCl}$. The released hippuric acid (HA) was extracted with ethyl acetate $(1.7 \mathrm{~mL})$ and then evaporated for $10 \mathrm{~min}$ at $95{ }^{\circ} \mathrm{C}$. The residue was dissolved in $1 \mathrm{~mL}$ of distilled water, after which absorbance was determined spectrophotometrically at $228 \mathrm{~nm}$ with buffer as blank.

Angiotensin I-converting enzyme inhibitory activity was calculated using the following equation:

$\operatorname{ACE}$ inhibition $(\%)=\left[1-\frac{(A 1-A 2)}{A 3}\right] \times 100$,

where $A 1$ is the sample's absorbance with ACE and inhibitor; $A 2$ is the sample's absorbance with inhibitor and without
ACE; finally, $A 3$ is the sample's absorbance with ACE and without inhibitor. All assays were performed in triplicate.

\section{Peptide Identification in Final Hydrolysates}

Hydrolysates obtained after simulated gastrointestinal hydrolysis and absorption were concentrated in the evaporator and dissolved in $2 \mathrm{~mL}$ of $0.01 \mathrm{M} \mathrm{HCl}$ prior to chromatographic analysis by LC-MS/MS (liquid chromatography coupled to tandem mass spectrometry) using nanoACQUITY (Waters) LC system and Orbitrap Velos mass spectrometer (Thermo Electron Corp., San Jose, CA, USA). The peptide mixture was applied to a nano-HPLC RP-C18 column (nanoACQUITY BEH C18 Waters 186003545) using an acetonitrile gradient $(0-35 \%$ AcN over $180 \mathrm{~min}$, in the presence of $0.05 \%$ formic acid with the flow rate of $250 \mathrm{~nL} / \mathrm{min}$ ). The data was processed with Mascot Distiller (http://www.matrixscience.com/distiller.html), followed by Mascot search engine (Mascot Daemon v. 2.4.0, Mascot Server v.2.4.1). (Matrix Science, London, UK); then, it was compared to the UniProt Knowledgebase (http://www. uniprot.org; access December 2017) (UniProt 2017). The search parameters used for precursor ions and mass tolerance products were $10 \mathrm{ppm}$ and $0.1 \mathrm{Da}$. The peptide sequences, acquired through liquid chromatography-tandem mass spectrometry analyses of hydrolysates, were analyzed using the in silico approach with tools from the BIOPEP-UWM database (http://www.uwm.edu.pl/biochemia/index.php/pl/ biopep; access December 2017), i.e. "Profiles of potential biological activity" to distinguish the fragments with ACE inhibitory properties and "Calculations" to determine the frequency occurrence of bioactive fragments in a protein sequence (A parameter) (Minkiewicz et al. 2008).

\section{Statistical Analysis}

The data were analyzed using the two-way ANOVA analysis to test the effect of inoculation and ageing time using SAS statistical software. Tukey's post hoc test was used to compare mean values. The differences were considered to be statistically significant at $p<0.05$. For hierarchical cluster analysis (HCA), Ward's method was conducted.

\section{Results and Discussion}

The significance levels of the experimental factors, as found using the ANOVA analysis, are shown in Table 1. Treatment (inoculation) and ageing time as well as the interactions between factors demonstrated a significant effect on ACE inhibitory activity of WSF and SSF protein fractions of the dry-cured loins before and after each step of simulated gastrointestinal processes of hydrolysis and absorption. 
Table 1 Significance levels showed by the experimental factors and their interactions for the ACE inhibitory activity of dry-cured loins after simulated gastrointestinal hydrolysis and absorption

\begin{tabular}{|c|c|c|c|c|}
\hline \multirow[t]{2}{*}{ Factor } & \multicolumn{4}{|c|}{ ACE inhibitory activity (\%) } \\
\hline & $\begin{array}{l}\text { Before } \\
\text { hydroly- } \\
\text { sis }\end{array}$ & $\begin{array}{l}\text { After pepsin } \\
\text { hydrolysis }\end{array}$ & $\begin{array}{l}\text { After pepsin/ } \\
\text { pancreatin } \\
\text { hydrolysis }\end{array}$ & $\begin{array}{l}\text { After } \\
\text { simulated } \\
\text { absorp- } \\
\text { tion }\end{array}$ \\
\hline
\end{tabular}

\begin{tabular}{|c|c|c|c|c|}
\hline \multicolumn{5}{|l|}{ WSF } \\
\hline $\begin{array}{l}\text { Treatment } \\
\text { (T) }\end{array}$ & $*$ & $* *$ & $* *$ & $* *$ \\
\hline $\begin{array}{l}\text { Ageing time } \\
\text { (S) }\end{array}$ & $* *$ & $* *$ & $* *$ & $* *$ \\
\hline $\mathrm{TxS}$ & $* *$ & $* *$ & $* *$ & $* *$ \\
\hline \multicolumn{5}{|l|}{ SSF } \\
\hline $\begin{array}{l}\text { Treatment } \\
\text { (T) }\end{array}$ & ns & $* *$ & $* *$ & $* *$ \\
\hline $\begin{array}{l}\text { Ageing time } \\
\text { (S) }\end{array}$ & $* *$ & $* *$ & $* *$ & $* *$ \\
\hline TxS & $* *$ & $* *$ & $* *$ & $* *$ \\
\hline
\end{tabular}

$n s$ nonsignificant

$* p<0.05, * * p<0.01$

\section{Assessment of ACE Inhibitory Activity After Simulated Gastrointestinal Hydrolysis and Absorption}

Meat proteins contain several regions within their primary structures where latent biological activities are encrypted. This specific peptide sequence can be released through proteolytic degradation during long-term ageing or hydrolysis by gastrointestinal enzymes during meat consumption (Stadnik and Kęska 2015). Some peptides, i.e. AAPLAP ( $\mathrm{IC}_{50}$ value of $14.38 \mu \mathrm{M}$ ) and KPVAAP ( IC $_{50}$ value of $\left.12.37 \mu \mathrm{M}\right)$, obtained from dry cured ham, are identified as potent ACE inhibitors (Escudero et al. 2013, 2014). Moreover, Escudero et al. (2014) have reported that ACE inhibition of peptides obtained from dry cured ham persists even after in vitro hydrolysis with gastric proteases. In addition, AAATP peptide with $\mathrm{IC}_{50}$ value of $100 \mu \mathrm{M}$ from dry-cured ham was found to show strong in vivo antihypertensive activity in the SHR model (Escudero et al. 2013).

In this study, the potential of ACE inhibitory activity of protein breakdown products of WSF and SSF protein extracts from LAB-inoculated dry-cured pork loins and their hydrolysates after simulated gastrointestinal hydrolysis with pepsin and pancreatin was assessed at different ageing times. As shown in Tables 2 and 3, the increasing ageing time was coupled with an increase of ACE inhibitory activity of WSF and SSF protein extracts. Regarding WSF (Table 2), after 90 days of ageing, the highest ACE inhibitory activity $(p<0.05)$ was observed in the BB12 sample $(44.40 \%)$. At the next sampling point, the highest inhibitory effect was achieved for loins with BAUER. Samples with both the strains had statistically significantly higher ACE inhibitory properties $(\%)$ compared to C and LOCK $(p<0.05)$ at 270 days. At the end of the ageing process, the ACE inhibitory activity of the $\mathrm{C}$ was highest among the samples, which was followed by activity of the LOCK and BB12 samples. Finally, activity of the sample containing L. acidophilus Bauer $Ł 0938$ was the least. The ACE inhibitory activity of the loins without LAB might be a result of the degradation products generated by endogenous proteases; this was previously described by Sentandreu et al. (2002). As far as SSF is concerned (Table 3), the highest ACE inhibitory effects were observed in loins with BAUER, after ageing for 90 and 180 days ( $42.67 \%$ and $65.02 \%$, respectively) and $C$ in 360 days $(66.29 \%)$. There were no statistically significant differences between the samples after 270 days of ageing $(p>0.05)$. Takeda et al. (2017) also reported that the ACE inhibitory activity of products fermented with LAB was higher than the activity in those fermented without LAB.

In previous studies, ACE inhibitory peptides, such as KRQKYD and EKERERQ or KRVITY, were isolated from pork proteins digested with pepsin (Katayama et al. 2008; Muguruma et al. 2009). To verify if active peptides can be efficiently produced by hydrolysis in the gastrointestinal tract, the protein extracts obtained from LAB-inoculated dry-cured pork loins were subjected to two-stage hydrolysis by pepsin and pancreatin under simulated physiological conditions. After in vitro hydrolysis, the hydrolysates obtained showed strong ACE inhibitory activity (Tables 2, 3). However, the trend of changes at individual hydrolysis stages was ambiguous. In most cases, the increase the hydrolysates' ACE inhibitory activity was observed after gastric hydrolysis ( $\mathrm{pH} 2$ at $37^{\circ} \mathrm{C}$ for $2 \mathrm{~h}$ ) when compared to the undigested protein extracts. This result is not surprising, because pepsin is a non-specific enzyme with high activity, generating a large number of shorter sequences from the protein chain. This may lead to new peptides that have ACE inhibitory activity being generated with greater exposure of hydrophobic residues after pepsin treatment (Zuo et al. 2017). For WSF, the highest ACE inhibitory activity was achieved after 180 days of aging (except LOCK), caused by hydrolytic degradation of proteins through the action of pepsin (Table 2). Concerning SSF (Table 3), the pepsin hydrolysates had the maximum value of ACE inhibition after 360 days (except LOCK). During this period significantly highest $(p<0.05)$ value of biological activity was obtained for the BAUER sample (81.98\%). Subsequent pancreatin hydrolysis reduced the ACE inhibitory activity of WSF (Table 2). This was likely to occur due to the hydrolysis of ACE inhibitory peptides into less active peptide fragments or free amino acids, after pancreatin hydrolysis. Since ACE inhibitory activity is measured based on the total protein material in each 
Table 2 ACE inhibitory activity of water-soluble fraction (WSF) protein hydrolysates $(1 \mathrm{mg} / \mathrm{mL})$ after simulated gastrointestinal hydrolysis and absorption

\begin{tabular}{|c|c|c|c|c|c|}
\hline \multirow[t]{2}{*}{ Sample } & \multirow{2}{*}{$\begin{array}{l}\text { Ageing time } \\
\text { (days) }\end{array}$} & \multicolumn{4}{|c|}{ ACE inhibitory activity (\%) } \\
\hline & & $\mathrm{C}$ & LOCK & BAUER & BB12 \\
\hline \multirow[t]{4}{*}{ Before hydrolysis } & 90 & $36.13^{\mathrm{cB}} \pm 1.53$ & $42.43^{\mathrm{cAB}} \pm 2.71$ & $35.12^{\mathrm{cB}} \pm 2.97$ & $44.40^{\mathrm{dA}} \pm 3.32$ \\
\hline & 180 & $53.09^{\mathrm{bBC}} \pm 2.40$ & $55.96^{\mathrm{bB}} \pm 3.17$ & $66.29^{\mathrm{aA}} \pm 1.13$ & $49.69^{c \mathrm{C}} \pm 1.94$ \\
\hline & 270 & $57.75^{\mathrm{bB}} \pm 1.36$ & $46.17^{\mathrm{cC}} \pm 3.01$ & $66.85^{\mathrm{aA}} \pm 2.44$ & $69.92^{\mathrm{aA}} \pm 1.47$ \\
\hline & 360 & $73.13^{\mathrm{aA}} \pm 1.65$ & $66.05^{\mathrm{aB}} \pm 2.65$ & $53.69^{\mathrm{bC}} \pm 1.25$ & $58.32^{\mathrm{bC}} \pm 1.53$ \\
\hline \multirow[t]{4}{*}{ After pepsin hydrolysis } & 90 & $43.28^{\mathrm{dA}} \pm 2.30$ & $43.35^{\mathrm{cA}} \pm 2.35$ & $32.47^{\mathrm{cB}} \pm 0.30$ & $27.13^{\mathrm{dC}} \pm 1.76$ \\
\hline & 180 & $75.79^{\mathrm{aA}} \pm 3.14$ & $65.87^{\mathrm{bB}} \pm 1.81$ & $71.18^{\mathrm{aAB}} \pm 4.98$ & $73.15^{\mathrm{aAB}} \pm 2.76$ \\
\hline & 270 & $54.79^{\mathrm{cB}} \pm 1.71$ & $49.08^{\mathrm{cC}} \pm 2.90$ & $64.82^{\mathrm{aA}} \pm 1.36$ & $56.34^{\mathrm{cB}} \pm 1.83$ \\
\hline & 360 & $68.60^{\mathrm{bB}} \pm 2.13$ & $78.20^{\mathrm{aA}} \pm 1.70$ & $63.08^{\mathrm{bB}} \pm 2.25$ & $65.94^{\mathrm{bB}} \pm 3.76$ \\
\hline \multirow[t]{4}{*}{ After pepsin/pancreatin hydrolysis } & 90 & $22.27^{\mathrm{dD}} \pm 1.87$ & $34.04^{\mathrm{cB}} \pm 2.21$ & $27.41^{\mathrm{cC}} \pm 1.01$ & $50.94^{\mathrm{cA}} \pm 1.23$ \\
\hline & 180 & $64.58^{\mathrm{aA}} \pm 2.25$ & $53.79^{\mathrm{bB}} \pm 1.30$ & $48.16^{\mathrm{bC}} \pm 1.67$ & $67.19^{\mathrm{aB}} \pm 1.36$ \\
\hline & 270 & $42.62^{\mathrm{cC}} \pm 2.17$ & $65.46^{\mathrm{aA}} \pm 2.02$ & $57.29^{\mathrm{aB}} \pm 3.71$ & $56.16^{\mathrm{bcB}} \pm 1.20$ \\
\hline & 360 & $58.94^{\mathrm{bB}} \pm 3.04$ & $72.38^{\mathrm{aA}} \pm 4.38$ & $56.77^{\mathrm{aB}} \pm 0.54$ & $59.11^{\mathrm{abB}} \pm 3.32$ \\
\hline \multirow[t]{4}{*}{ After simulated absorption } & 90 & $19.76^{\mathrm{cB}} \pm 3.46$ & $34.77^{\mathrm{cA}} \pm 2.82$ & $22.30^{\mathrm{dB}} \pm 2.00$ & $30.60^{\mathrm{dA}} \pm 1.06$ \\
\hline & 180 & $65.78^{\mathrm{aA}} \pm 1.26$ & $54.53^{\mathrm{bB}} \pm 0.06$ & $49.10^{\mathrm{cC}} \pm 0.54$ & $67.07^{\mathrm{aA}} \pm 1.89$ \\
\hline & 270 & $64.32^{\mathrm{aA}} \pm 2.78$ & $62.43^{\mathrm{aA}} \pm 1.62$ & $58.35^{\mathrm{bA}} \pm 2.33$ & $60.55^{\mathrm{bA}} \pm 2.43$ \\
\hline & 360 & $48.38^{\mathrm{bC}} \pm 2.66$ & $56.83^{\mathrm{bB}} \pm 1.59$ & $64.71^{\mathrm{aA}} \pm 1.08$ & $55.38^{\mathrm{cB}} \pm 2.03$ \\
\hline
\end{tabular}

Each data point represents the mean of triplicate \pm SD

C control sample, LOCK sample inoculated with Lactobacillus rhamnosus LOCK900, BAUER sample inoculated with Lactobacillus acidophilus Bauer Ł0938, BB12 sample inoculated with Bifidobacterium animalis ssp. lactis BB-12

${ }^{\mathrm{a}-\mathrm{d}}$ Within the same treatment (column), values with different superscripts were significantly different at $p<0.05$

${ }^{\mathrm{A}-\mathrm{D}}$ Within the same ageing time (verse), values with different superscripts were significantly different at $p<0.05$

fraction, decrease in activity after pancreatin hydrolysis may be caused by new peptides formation without significant ACE inhibitory activity. Samaranayaka et al. (2010) reported that the ACE inhibitory activity of fish protein hydrolysate decreased after hydrolysis by pepsin and pancreatic enzyme. Wu and Ding (2002) reported that ACE inhibitory activity of soy protein hydrolysates decreased $\left(\mathrm{IC}_{50}\right.$ increased from 0.065 to $0.073 \mathrm{mg} / \mathrm{mL}$ ) after pepsin-pancreatin in vitro hydrolysis. This observation was also made by others (Jao et al. 2012; Miguel et al. 2006; Norris and FitzGerald 2013; Samaranayaka et al. 2010; Tavares et al. 2011; Toopcham et al. 2017). However, as Zuo et al. (2017) reported, ACE inhibition of peptides extracted from dry-cured Jinhua ham increased by $4.01 \%$ after pepsin treatment; subsequently, they remained constant after trypsin hydrolysis.

On the other hand, the results obtained for SSF indicate the relative stability of ACE inhibitory activity of protein breakdown products despite further intestinal (pancreatin) hydrolysis (Table 3). Samples aged for 180 days showed an increase in ACE inhibitory activity (for $\mathrm{C}$ of $50 \%$, and for BAUER of 22\%) after pancreatic hydrolysis, which indicated that intestinal enzymes may be beneficial to release more active peptides responsible for ACE inhibition in this samples. Moreover, it appears that the hydrolysates obtained from samples inoculated with probiotic strains of $\mathrm{LAB}$ result in better stability of the ACE activity of SSF, when considering the intact extracts versus products derived as a result of in vitro gastrointestinal hydrolysis and absorption after 180 , 270 , and 360 days of ageing (Table 3).

To exert antihypertensive activity in vivo, ACE inhibitory peptides must be resistant to gastrointestinal degradation as well as be absorbed into the bloodstream completely intact. The most interesting are the small ACE inhibitory peptides (2-6 amino acids), because they are most likely absorbed into the bloodstream (Yamamoto 1997). To identify small peptides exhibiting the potential effect of ACE inhibition, WSF and SSF hydrolysates were suitably filtered with a $7 \mathrm{kDa}$ cut-off membrane as a simulated absorption step. The effect of ageing time and LAB inoculation on the ACE inhibitory activity of hydrolysates after hydrolysis and simulated in vitro absorption is shown in Fig. 1. The highest ACE inhibitory properties were seen in peptides from WSF hydrolysates of the variant $\mathrm{C}$ after 180 and 270 days $(65.78 \%$ and $64.32 \%$, respectively) and after 180 days of pork inoculated with BB12 strain (67.07\%) (Fig. 1a). Concerning the SSF fraction, the BB12 variant reached the highest ACE inhibitory activity after 270 days of ageing (Fig. 1b).

LAB-inoculated samples, particularly their SSF (Fig. 2d), were characterized by the greatest similarity in ACE inhibition. The WSF of LOCK and BAUER clearly formed a 
Table 3 ACE inhibitory activity of salt-soluble fraction (SSF) protein hydrolysates $(1 \mathrm{mg} / \mathrm{mL})$ after simulated gastrointestinal hydrolysis and absorption

\begin{tabular}{|c|c|c|c|c|c|}
\hline \multirow[t]{2}{*}{ Sample } & \multirow{2}{*}{$\begin{array}{l}\text { Ageing time } \\
\text { (days) }\end{array}$} & \multicolumn{4}{|c|}{ ACE inhibitory activity (\%) } \\
\hline & & $\mathrm{C}$ & LOCK & BAUER & BB12 \\
\hline \multirow[t]{4}{*}{ Before hydrolysis } & 90 & $38.32^{\mathrm{cB}} \pm 2.86$ & $38.86^{\mathrm{bB}} \pm 0.53$ & $42.67^{\mathrm{cA}} \pm 2.65$ & $36.24^{\mathrm{cB}} \pm 1.40$ \\
\hline & 180 & $61.18^{\mathrm{aAB}} \pm 0.48$ & $59.91^{\mathrm{aAB}} \pm 2.22$ & $65.02^{\mathrm{aA}} \pm 3.59$ & $57.56^{\mathrm{abB}} \pm 2.73$ \\
\hline & 270 & $58.66^{\mathrm{bA}} \pm 2.54$ & $59.16^{\mathrm{aA}} \pm 2.96$ & $58.23^{\mathrm{abA}} \pm 2.84$ & $56.80^{\mathrm{bA}} \pm 2.30$ \\
\hline & 360 & $66.29^{\mathrm{aA}} \pm 3.19$ & $60.47^{\mathrm{aAB}} \pm 1.30$ & $55.61^{\mathrm{bB}} \pm 3.29$ & $62.94^{\mathrm{aA}} \pm 2.67$ \\
\hline \multirow[t]{4}{*}{ After pepsin hydrolysis } & 90 & $40.73^{\mathrm{cA}} \pm 3.74$ & $32.91^{\mathrm{cBC}} \pm 0.99$ & $28.31^{\mathrm{dC}} \pm 1.35$ & $36.10^{\mathrm{bB}} \pm 1.76$ \\
\hline & 180 & $54.81^{\mathrm{bB}} \pm 4.27$ & $69.82^{\mathrm{aA}} \pm 2.65$ & $56.17^{\mathrm{cB}} \pm 2.16$ & $74.05^{\mathrm{aA}} \pm 1.94$ \\
\hline & 270 & $60.09^{\mathrm{bB}} \pm 2.83$ & $62.96^{\mathrm{bB}} \pm 3.30$ & $72.79^{\mathrm{bA}} \pm 1.86$ & $72.47^{\mathrm{aA}} \pm 3.62$ \\
\hline & 360 & $73.36^{\mathrm{aB}} \pm 1.37$ & $63.18^{\mathrm{bC}} \pm 1,34$ & $81.98^{\mathrm{aA}} \pm 1.38$ & $74.70^{\mathrm{aB}} \pm 3.29$ \\
\hline \multirow[t]{4}{*}{ After pepsin/pancreatin hydrolysis } & 90 & $39.88^{\mathrm{cA}} \pm 1.47$ & $35.43^{\mathrm{cAB}} \pm 3.33$ & $24.44^{\mathrm{cC}} \pm 2.37$ & $32.10^{\mathrm{cB}} \pm 2.60$ \\
\hline & 180 & $81.27^{\mathrm{aA}} \pm 2.04$ & $70.37^{\mathrm{aB}} \pm 2.39$ & $68.82^{\mathrm{aB}} \pm 0.92$ & $72.17^{\mathrm{aB}} \pm 1.08$ \\
\hline & 270 & $63.75^{\mathrm{bB}} \pm 0.26$ & $65.95^{\mathrm{abB}} \pm 3.29$ & $53.74^{\mathrm{bB}} \pm 2.34$ & $70.15^{\mathrm{abA}} \pm 2.92$ \\
\hline & 360 & $61.57^{\mathrm{bB}} \pm 2.17$ & $60.66^{\mathrm{bB}} \pm 2.87$ & $72.35^{\mathrm{aA}} \pm 0.71$ & $65.84^{\mathrm{bB}} \pm 1.77$ \\
\hline \multirow[t]{4}{*}{ After simulated absorption } & 90 & $30.03^{\mathrm{cAB}} \pm 3.03$ & $32.23^{\mathrm{bA}} \pm 3.58$ & $29.93^{\mathrm{bAB}} \pm 2.11$ & $24.41^{\mathrm{dB}} \pm 0.91$ \\
\hline & 180 & $43.88^{\mathrm{bC}} \pm 3.04$ & $57.60^{\mathrm{aB}} \pm 3.71$ & $66.40^{\mathrm{aA}} \pm 2.13$ & $51.69^{\mathrm{cB}} \pm 0.52$ \\
\hline & 270 & $55.83^{\mathrm{aC}} \pm 3.90$ & $58.78^{\mathrm{aBC}} \pm 0.73$ & $63.11^{\mathrm{aB}} \pm 1.24$ & $71.19^{\mathrm{aA}} \pm 1.06$ \\
\hline & 360 & $49.81^{\mathrm{abC}} \pm 1.93$ & $57.92^{\mathrm{aB}} \pm 1.95$ & $63.02^{\mathrm{aA}} \pm 1.35$ & $56.55^{\mathrm{bB}} \pm 1.37$ \\
\hline
\end{tabular}

Each data point represents the mean of triplicate $\pm \mathrm{SD}$

C control sample, LOCK sample inoculated with Lactobacillus rhamnosus LOCK900, BAUER sample inoculated with Lactobacillus acidophilus Bauer Ł0938, BB12 sample inoculated with Bifidobacterium animalis ssp. lactis BB-12

${ }^{\mathrm{A}-\mathrm{D}}$ Within the same ageing time (verse), values with different superscripts were significantly different at $p<0.05$

${ }^{\mathrm{a}-\mathrm{d}}$ Within the same treatment (column), values with different superscripts were significantly different at $p<0.05$

distinct group, as shown in Fig. 2c, and the ACE inhibitory results for them were closely connected to one another. Based on the HCA results, 180 days was indicated as optimal time for ageing of dry-cured pork loins (Fig. 2a, b) in terms of ACE inhibitory activity. Therefore, hydrolysates after in vitro hydrolysis and absorption obtained after this time were subjected to further analyses based on chromatographic methods.

\section{Characterization of Final Hydrolysates}

To exert antihypertensive activity in in vivo conditions, ACE inhibitory peptides must survive the gastrointestinal passage in an active form and enter the site of action through the blood circulatory system. In addition, the smaller peptides that are produced in the final steps of hydrolysis/hydrolysis are more potent ACE inhibitors than the larger peptides. This is probably because they better match the active site of ACE, the purpose of which is to alter its activity (Iwaniak et al. 2014).

To identify the precursors of ACE inhibiting peptides, their sequences were identified and characterized using LC-MS/MS. Subsequently, the identification was confirmed through exact mass determination using LTQ-Orbitrap. The analyses were performed in two independent tests; only the doubling sequences were selected for the next step. Of these, 98\% (1142 sequences) were identified as potential ACE inhibitory sequences based on in silico analysis in the BIOPEP-UWM database (Minkiewicz et al. 2008). Of these, 46 sequences with the greatest abundance of ACE inhibitory fragments (based on $A$ parameter) were selected, and the results are shown in Table 4 . The selected sequences were composed of 6-22 amino acids.

Similarly, the comparable molecular weight peptides (23 amino acids) from milk proteins (casein-derived peptides) fermented using Lactobacillus helveticus NCC 2765 (Robert et al. 2004) significantly inhibited ACE activity. Indeed, ACE inhibitory peptides usually contain from 2 to 12 amino acids (He et al. 2013; Iwaniak et al. 2014; Nasri et al. 2013). Nevertheless, some oligopeptides may be cleaved into several smaller fragments. The outcome of the degradation depends on the fragments produced where it may increase or reduce the overall ACE inhibitory activity (Manoharan et al. 2017). In this context, the most abundant ACE inhibitory sequences were detected in longer peptides, i.e. TPPPPPPG $(A=1.3750)$ and KEGGLGPL $(A=1.1250)$ (Fig. 3a, b), which could be degraded to shorter bioactive peptides (Table 4). In addition, almost half the obtained sequences came from myosin light chain (MLC) isoform MLC1f. As an example, the sequence of the longest peptide 
Fig. 1 Response surface plot of the effect of treatment and ageing time on ACE inhibitory activity after in vitro gastrointestinal hydrolysis and simulated absorption of WSF (A) and SSF (B)

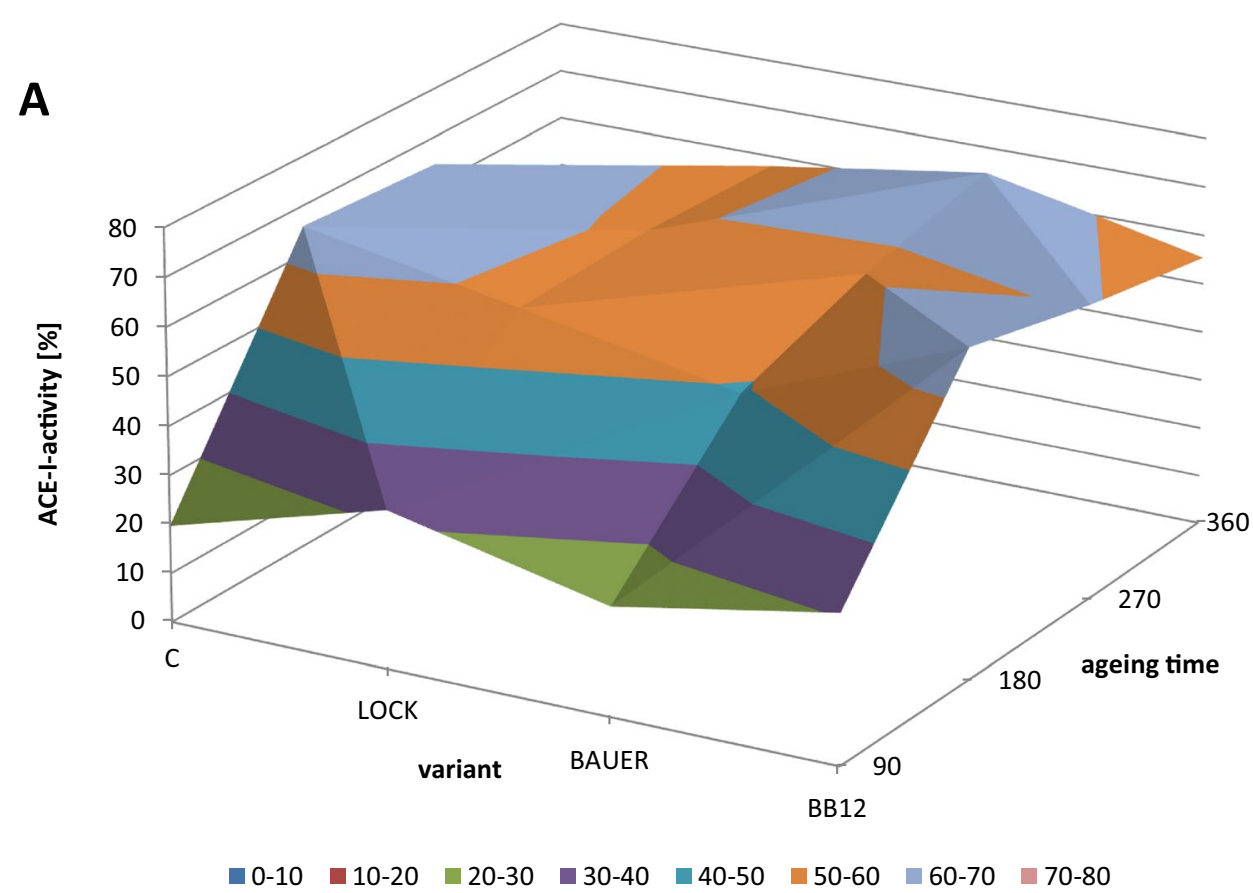

B

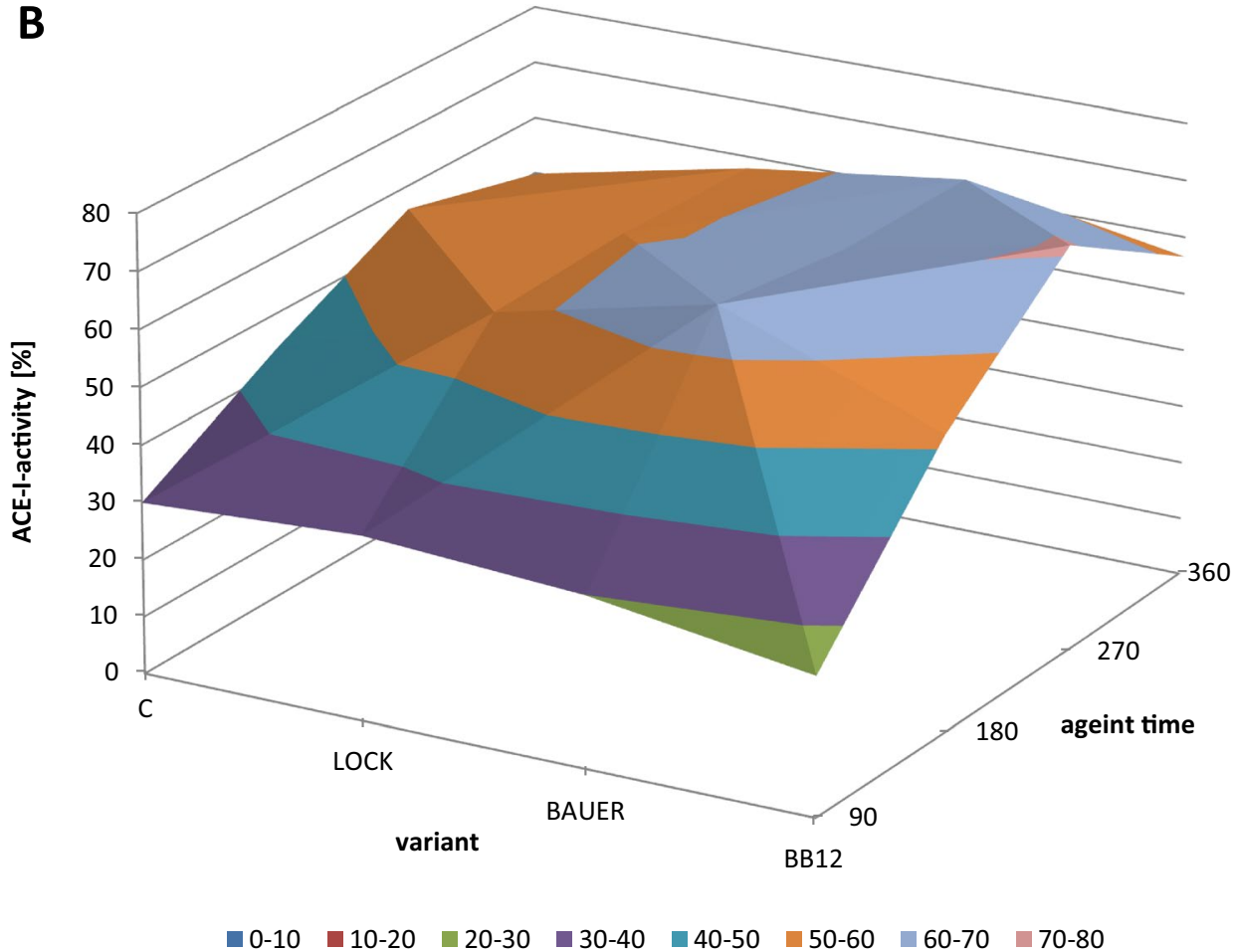

(22 amino acids) from this protein is shown in Fig. 3c. Muguruma et al. (2009) identified a novel ACE inhibitory peptide (KRVITY) from porcine skeletal myosin after pepsin hydrolysis. Kinetic evaluations showed that this peptide is a competitive inhibitor of ACE. Based on its activity against
$\mathrm{ACE}$, it was determined to be a pro-drug type of inhibitory peptide, i.e. it shows an increase in ACE inhibitory activity after being cleaved by ACE. When this myosin-originated peptide was administered orally at doses of $10 \mathrm{mg} / \mathrm{kg}$, systolic blood pressure in SHR decreased by $23 \mathrm{mmHg}$ in $6 \mathrm{~h}$, 

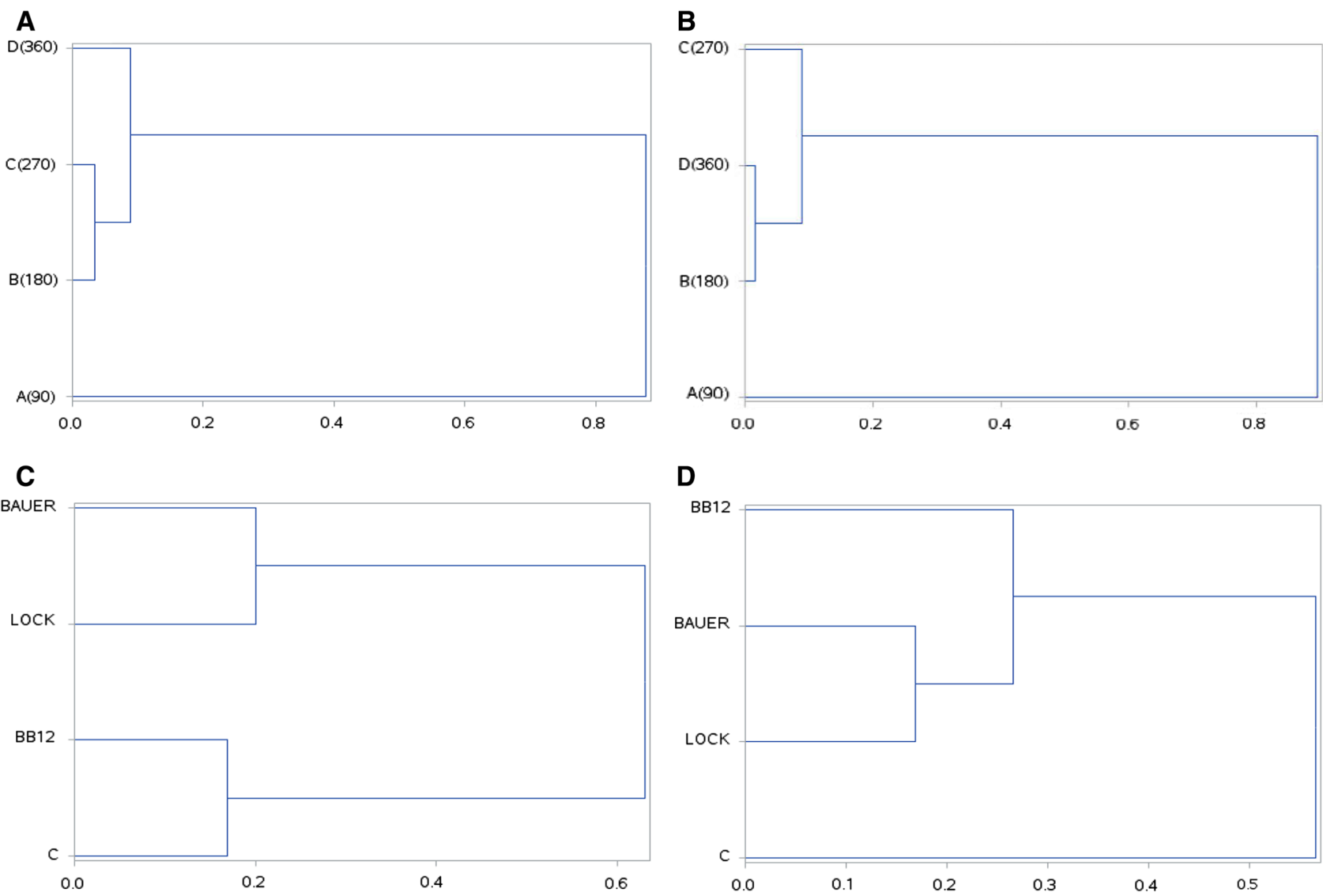

Fig. 2 Dendrogram resulting from the Ward's method of hierarchical cluster analysis of ACE inhibitory activity during long term ageing in WSF (A) or SSF (B) and according to lactic acid bacteria strain in WSF (C) and SSF (D)

indicating that this peptide has a strong effect on the reduction of blood pressure in mammals. The longest peptide sequence obtained (Fig. 3c), contained a total of 22 shorter sequences consisting of two or three amino acids with ACE inhibitory activity as shown in Table 4 . Some ACE inhibitors are active in vitro but not in vivo (Iwaniak et al. 2014; Vermeirssen et al. 2004), probably due to their degradation by the brush-border peptidases or plasma peptidases. These proteases are vital for the formation and degradation of bioactive peptides as well as their bioavailability and physiological effects (Miguel et al. 2006; Toopcham et al. 2017). These discrepancies may also be because peptides can affect BP through mechanisms other than ACE mode of action, i.e. interaction of the peptide with opioid receptors that are present in the nervous, hormonal, immunological, and intestinal systems (Iwaniak et al. 2014). These lead to the differing outcomes between in vitro ACE inhibition and in vivo BP lowering effects. Although the analytical conditions used in this study do not provide absolute certainty, it can be assumed that the resulting sequences after simulated hydrolysis and absorption of protein extracts from dry-cured pork loins can undergo partial degradation by enzymes during intestinal absorption to effectively bind to ACE molecules under in vivo conditions.

Certain peptide structures are resistant to hydrolysis in the gastrointestinal tract, because of the composition and position of the amino acids in their primary chains. The peptide hydrolysis rate depends on the peptide's amino acid composition as well (Norris and FitzGerald 2013). In this study, the di- and tripeptides were found based on BIOPEP-UWM database; small peptides are stable, especially when are rich in proline. These peptides are probably not further degraded by intestinal peptidases (Balti et al. 2010).

Several structural attributes have been found to influence binding of a peptide to the ACE active site. Most of the potent ACE-inhibitory peptides, especially di- and tripeptides, that are released by proteolytic hydrolysis contain hydrophobic amino acids (especially with aliphatic chains, i.e. Gly, Ile, Leu, and Val) on the N-terminus of the peptide as well as cyclic (Pro) and aromatic residues (Phe Tyr, Trp) at the C-terminus of the ACE inhibitor which imbues them with hydrophobic properties (Norris and FitzGerald 2013; Vermeirssen et al. 2004). Gómez-Ruiz et al. (2004) hypothesized that Leu could significantly 


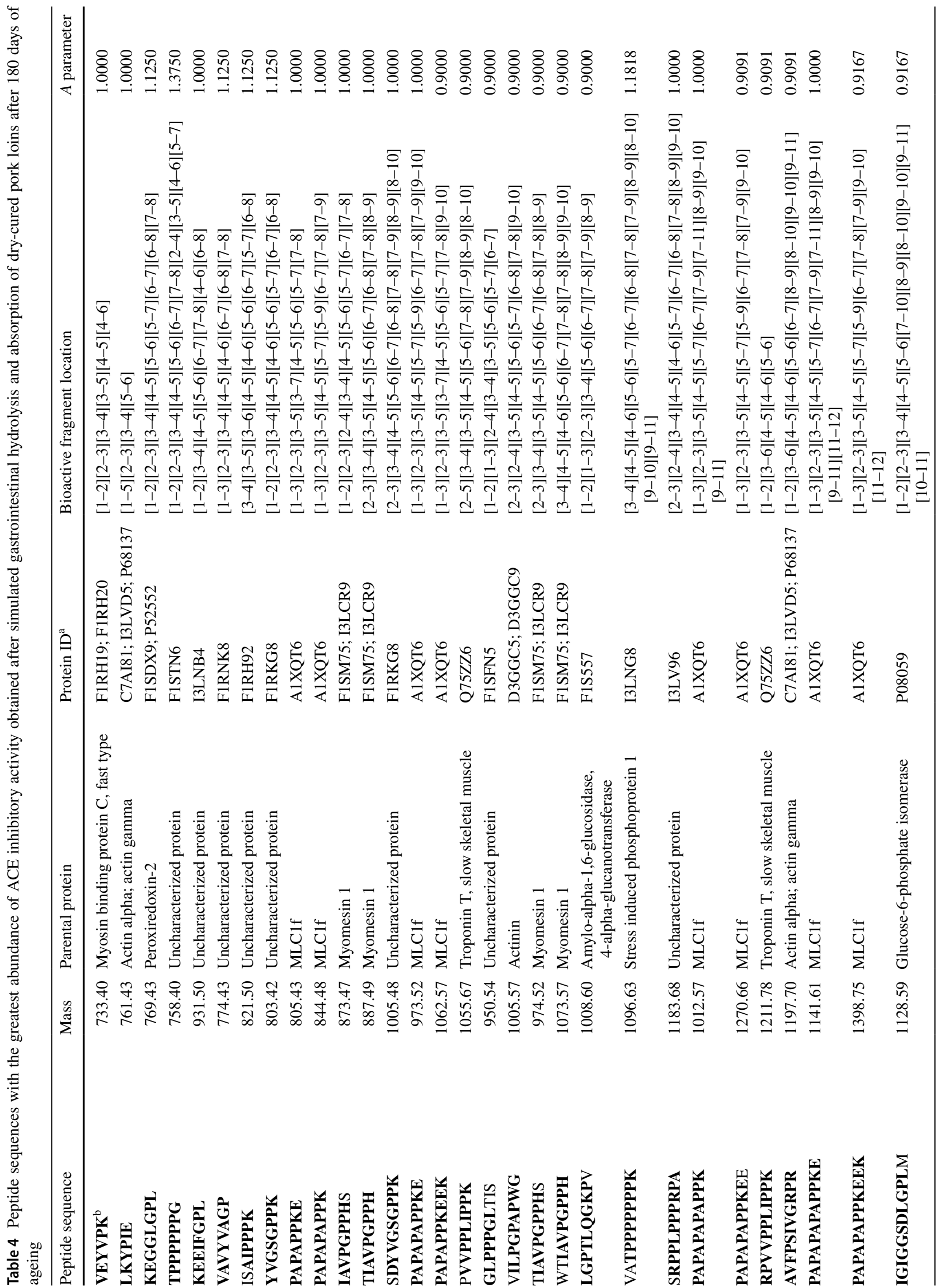




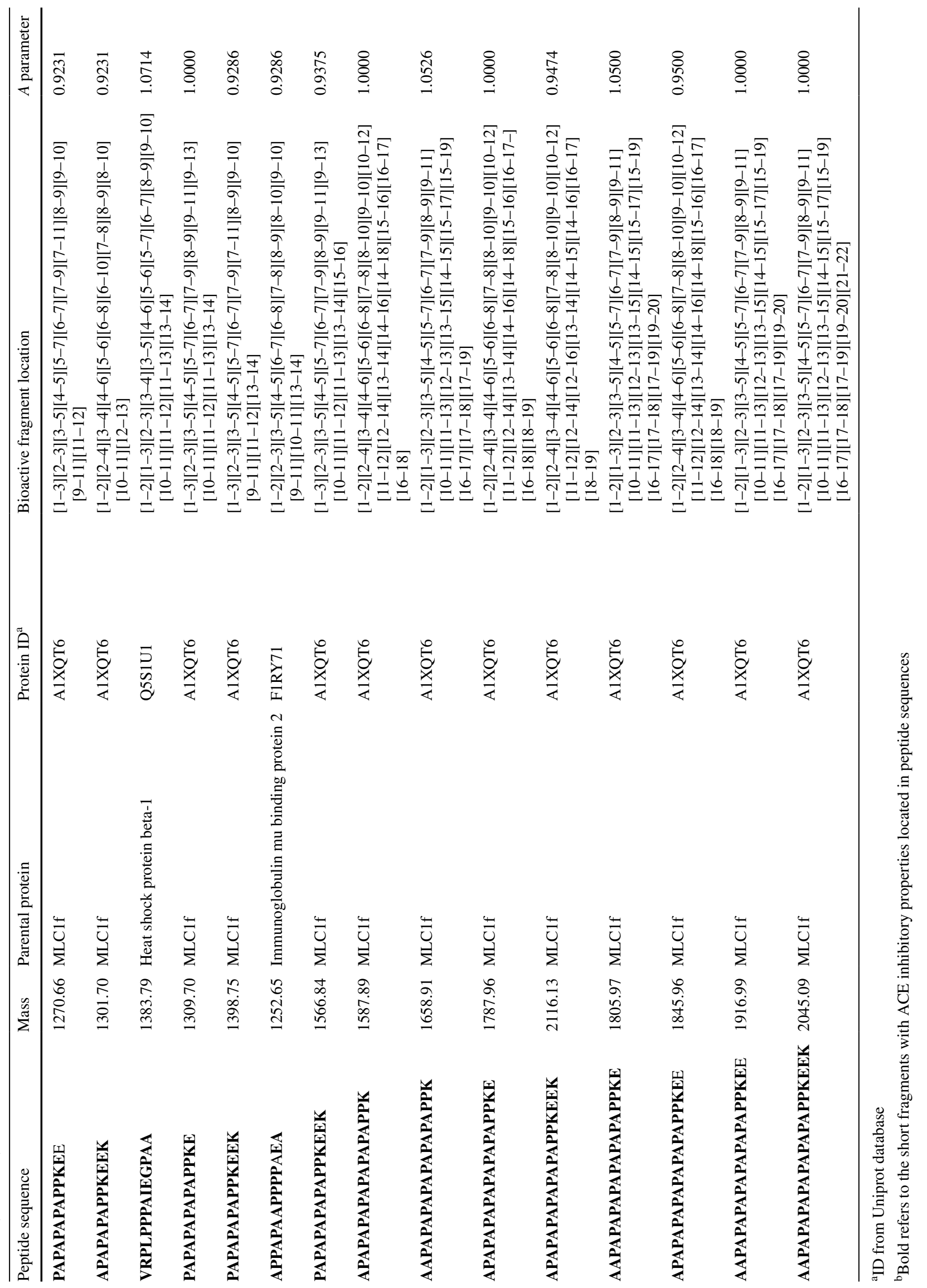




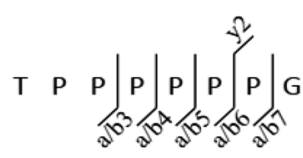

A
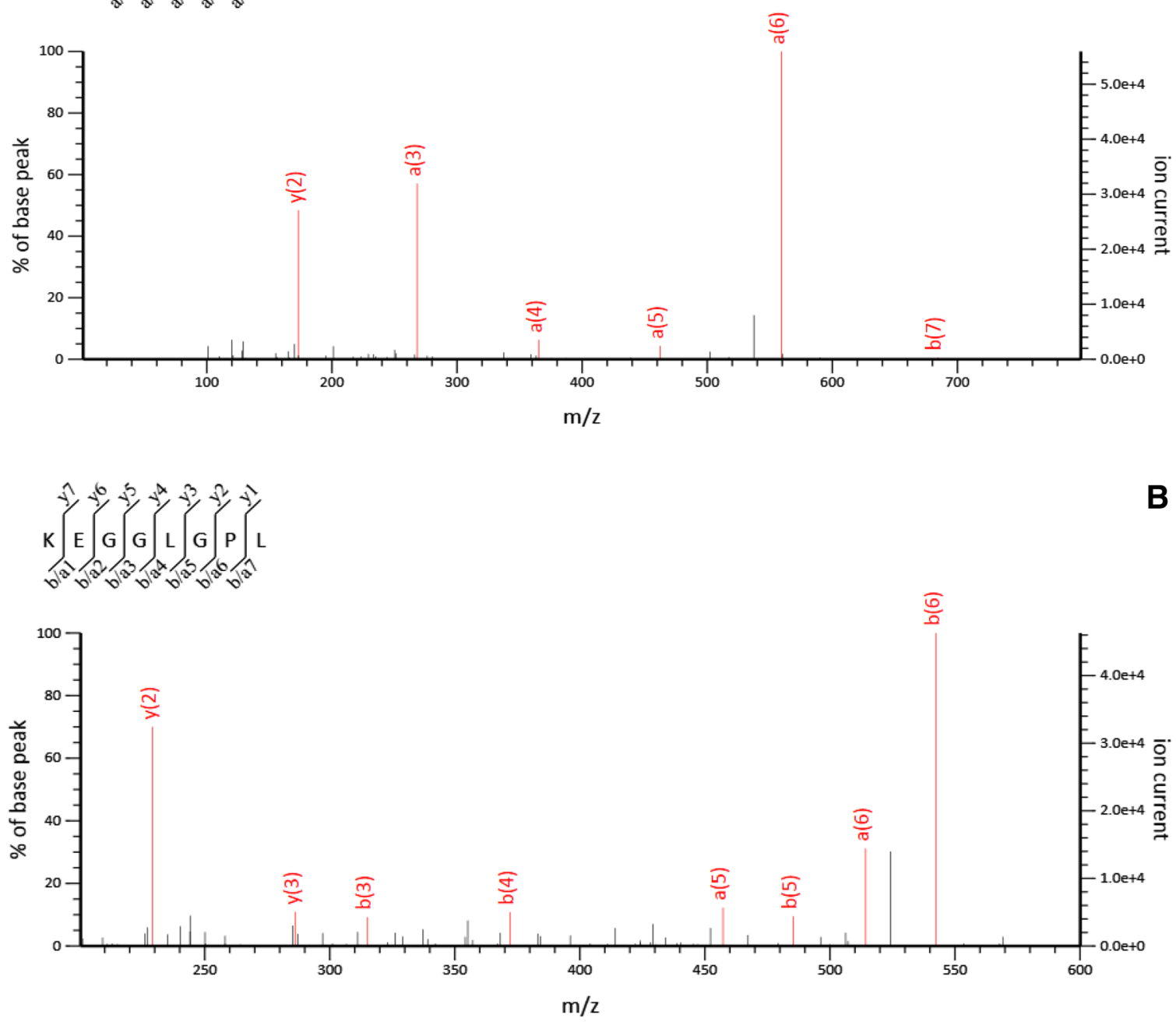

A $\left.A\right|_{10}$

C

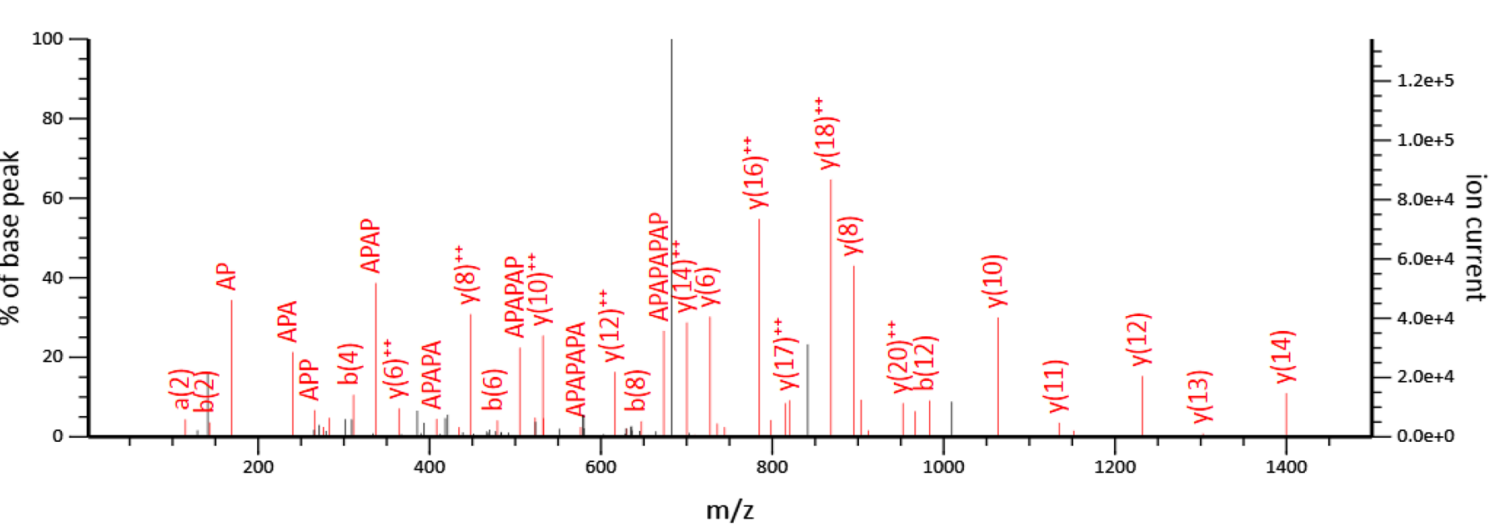

Fig. 3 LC-MS/MS spectra of TPPPPPPG (A) KEGGLGPL (B) and AAPAPAPAPAPAPAPAPPKEEK (C) peptides generated after in vitro hydrolysis and simulated absorption of dry-cured pork loins after 180 days of ageing 
contribute to increasing ACE inhibition potential. Additionally, the C-terminal hydrophobic Lys or Arg, with a positive charge on the $\varepsilon$-amino group, also contributes to the inhibition potential of peptides (Guang and Phillips 2009; Vermeirssen et al. 2004).

In this study, obtained peptides were mainly composed of Pro (P), Ala (A), Lys (K), and Glu (E) molecules, which is consistent with the trend for most of the known ACE inhibitors. Moskowitz (2002) suggested a model explaining the clinical superiority of hydrophobic ACE inhibitory drugs compared to hydrophilic ones. According to this model, all ACE inhibitors bind to the $\mathrm{C}$-terminus catalytic site, but only hydrophobic ones bind to the occlusion of the $\mathrm{N}$-terminal catalytic site; they are therefore better at blocking angiotensin II production. The high content of hydrophobic amino acids in the peptide fractions obtained in hydrolysates from dry-cured pork loins can therefore significantly contribute to the ACE-inhibitory activity of these fractions by blocking the production of angiotensin II.

\section{Conclusion}

The ACE inhibitory activity of WSF and SSF (undigested protein extracts obtained from dry cured pork loins) as well as of the hydrolysates obtained via in vitro hydrolysis have been confirmed. Hydrolysis of meat proteins during ageing significantly affects the peptide profile, especially after 180 and 270 days of ageing. The sequences obtained as a result of pepsin and pancreatin enzymatic hydrolysis had varied levels of activity; however, they retained their activity after simulated absorption in vitro. The influence of LAB, mainly among SSF, was also observed. According to the presented results, the ACE inhibitory peptides from drycured pork loins could be potential candidates to enable the development of functional foods. These foods could be used as nutraceutical compounds to treat hypertension and related diseases. In this regard, further studies are required to determine if there is a correlation between in vitro and in vivo hydrolysis. This will enable assessment of the bioavailability of potential ACE inhibitory peptides.

Acknowledgements The strains Lactobacillus rhamnosus LOCK900 and Lactobacillus acidophilus Bauer Ł0938 were provided by Professor Zdzisława Libudzisz and Dr. Ilona Motyl (Technical University of Łódź, Poland).

\section{Compliance with Ethical Standards}

Conflict of interest The authors have no conflict of interest to declare.

Open Access This article is distributed under the terms of the Creative Commons Attribution 4.0 International License (http://creativeco mmons.org/licenses/by/4.0/), which permits unrestricted use, distribution, and reproduction in any medium, provided you give appropriate credit to the original author(s) and the source, provide a link to the Creative Commons license, and indicate if changes were made.

\section{References}

Adler-Nissen J (1979) Determination of the degree of hydrolysis of food protein hydrolysates by trinitrobenzenesulfonic acid. J Agric Food Chem 27:1256-1262

Arihara K (2006) Strategies for designing novel functional meat products. Meat Sci 74:219-229. https://doi.org/10.1016/j.meats ci.2006.04.028

Arihara K, Nakashima Y, Mukai T, Ishikawa S, Itoh M (2001) Peptide inhibitors for angiotensin I-converting enzyme from enzymatic hydrolysates of porcine skeletal muscle proteins. Meat Sci 57:319-324

Balti R, Nedjar-Arroume N, Bougatef A, Guillochon D, Nasri M (2010) Three novel angiotensin I-converting enzyme (ACE) inhibitory peptides from cuttlefish (Sepia officinalis) using digestive proteases. Food Res Int 43:1136-1143. https://doi.org/10.1016/j. foodres.2010.02.013

Chockalingam A (2008) World Hypertension Day and global awareness. Can J Cardiol 24:441-444. https://doi.org/10.1016/S0828 $-282 \mathrm{X}(08) 70617-2$

Escudero E, Mora L, Fraser PD, Aristoy MC, Arihara K, Toldrá F (2013) Purification and identification of antihypertensive peptides in Spanish dry-cured ham. J Proteom 78:499-507. https:// doi.org/10.1016/j.jprot.2012.10.019

Escudero E, Mora L, Toldrá F (2014) Stability of ACE inhibitory ham peptides against heat treatment and in vitro digestion. Food Chem 161:305-311. https://doi.org/10.1016/j.foodchem.2014.03.117

Fadda S, Sanz Y, Vignolo G, Aristoy MC, Oliver G, Toldrá F (1999) Characterization of muscle sarcoplasmic and myofibrillar protein hydrolysis caused by Lactobacillus plantarum. Appl Environ Microb 65:3540-3546

Gallego M, Mora L, Toldrá F (2017) Health relevance of antihypertensive peptides in foods. Curr Opin Food Sci 19:8-14. https://doi. org/10.1016/j.cofs.2017.12.004

Gómez-Ruiz JA, Recio I, Belloque J (2004) ACE-Inhibitory activity and structural properties of peptide Asp-Lys-Ile-His-Pro $[\beta-\mathrm{CN}$ $\mathrm{f}(47-51)]$. Study of the peptide forms synthesized by different methods. J Agric Food Chem 52:6315-6319

Gornall AG, Bardawill CJ, David MM (1949) Determination of serum proteins by means of the biuret reaction. J Biol Chem 177:751-766

Guang C, Phillips RD (2009) Plant food-derived angiotensin I converting enzyme inhibitory peptides. J Agric Food Chem 57:51135120. https://doi.org/10.1021/jf900494d

He HL, Liu D, Ma CB (2013) Review on the angiotensin-I-converting enzyme (ACE) inhibitor peptides from marine proteins. Appl Biochem Biotechnol 169:738-749. https://doi.org/10.1007/s1201 0-012-0024-y

Hong F, Ming L, Yi S, Zhanxia L, Yongquan W, Chi L (2008) The antihypertensive effect of peptides: a novel alternative to drugs? Peptides 29:1062-1071. https://doi.org/10.1016/j.pepti des.2008.02.005

Iwaniak A, Minkiewicz P, Darewicz M (2014) Food-originating ACE inhibitors, including antihypertensive peptides, as preventive food components in blood pressure reduction. Compr Rev Food Sci Food Saf 13:114-134. https://doi.org/10.1111/1541-4337.12051

Jao CL, Huang SL, Hsu KC (2012) Angiotensin I-converting enzyme inhibitory peptides: inhibition mode, bioavailability, and 
antihypertensive effects. BioMedicine 2:130-136. https://doi. org/10.1016/j.biomed.2012.06.005

Katayama K et al (2007) Angiotensin-I converting enzyme inhibitory peptide derived from porcine skeletal muscle myosin and its antihypertensive activity in spontaneously hypertensive rats. J Food Sci 72:S702-S706. https://doi.org/10.111 1/j.1750-3841.2007.00571.x

Katayama K et al (2008) Porcine skeletal muscle troponin is a good source of peptides with angiotensin-I converting enzyme inhibitory activity and antihypertensive effects in spontaneously hypertensive rats. J Agric Food Chem 56:355-360. https://doi. org/10.1021/jf071408j

Kęska P, Stadnik J (2016) Porcine myofibrillar proteins as potential precursors of bioactive peptides-an in silico study. Food Funct 7:2878-2885. https://doi.org/10.1039/c5fo01631b

Kęska P, Stadnik J (2018) Stability of antiradical activity of protein extracts and hydrolysates from dry-cured pork loins with probiotic strains of LAB. Nutrients 10:521. https://doi.org/10.3390/ nu10040521

Manoharan S, Shuib AS, Abdullah N (2017) Structural characteristics and antihypertensive effects of angiotensin-I-converting enzyme inhibitory peptides in the renin-angiotensin and kallikrein kinin systems. Afr J Tradit Complement Altern Med 14:383-406. https ://doi.org/10.21010/ajtcam.v14i2.39

Miguel M, Aleixandre MA, Ramos M, Lopez-Fandino R (2006) Effect of simulated gastrointestinal digestion on the antihypertensive properties of ACE-inhibitory peptides derived from ovalbumin. $\mathrm{J}$ Agric Food Chem 54:726-731. https://doi.org/10.1021/jf051101p

Minkiewicz P, Dziuba J, Iwaniak A, Dziuba M, Darewicz M (2008) BIOPEP database and other programs for processing bioactive peptide sequences. J AOAC Int 91:965-980

Molina I, Toldra F (1992) Detection of proteolytic activity in microorganisms isolated from dry-cured ham. J Food Sci 57:1308-1310. https://doi.org/10.1111/j.1365-2621.1992.tb06843.x

Mora L, Fraser PD, Toldrá F (2013) Proteolysis follow-up in drycured meat products through proteomic approaches. Food Res Int 54:1292-1297. https://doi.org/10.1016/j.foodres.2012.09.042

Moskowitz DW (2002) Is "somatic" angiotensin I-converting enzyme a mechanosensor? Diabetes Technol Ther 4:841-858. https://doi. org/10.1089/152091502321118847

Muguruma M, Ahhmed AM, Katayama K, Kawahara S, Maruyama M, Nakamura T (2009) Identification of pro-drug type ACE inhibitory peptide sourced from porcine myosin B: evaluation of its antihypertensive effects in vivo. Food Chem 114:516-522. https ://doi.org/10.1016/j.foodchem.2008.09.081

Nakashima Y, Arihara K, Sasaki A, Mio H, Ishikawa S, Itoh M (2002) Antihypertensive activities of peptides derived from porcine skeletal muscle myosin in spontaneously hypertensive rats. J Food Sci 67:434-437. https://doi.org/10.1111/j.1365-2621.2002.tb11424.x

Nasri R, Chataigné G, Bougatef A, Chaâbouni MK, Dhulster P, Nasri M, Nedjar-Arroume N (2013) Novel angiotensin I-converting enzyme inhibitory peptides from enzymatic hydrolysates of goby (Zosterisessor ophiocephalus) muscle proteins. J Proteom 91:444-452. https://doi.org/10.1016/j.jprot.2013.07.029

Norris R, FitzGerald RJ (2013) Antihypertensive peptides from food proteins. In: Hernández-Ledesma B (ed) Bioactive food peptides in health and disease, IntechOpen, London, pp 45-72

Pessione E, Cirrincione S (2016) Bioactive molecules released in food by lactic acid bacteria: encrypted peptides and biogenic amines. Front Microbiol 7:876. https://doi.org/10.3389/fmicb.2016.00876
Robert MC, Razaname A, Mutter M, Juillerat MA (2004) Identification of angiotensin-I-converting enzyme inhibitory peptides derived from sodium caseinate hydrolysates produced by Lactobacillus helveticus NCC 2765. J Agric Food Chem 52:6923-6931. https ://doi.org/10.1021/jf049510t

Samaranayaka AG, Kitts DD, Li-Chan EC (2010) Antioxidative and angiotensin-I-converting enzyme inhibitory potential of a Pacific hake (Merluccius productus) fish protein hydrolysate subjected to simulated gastrointestinal digestion and Caco- 2 cell permeation. J Agric Food Chem 58:1535-1542. https://doi.org/10.1021/ jf9033199

Sentandreu MA, Coulis G, Ouali A (2002) Role of muscle endopeptidases and their inhibitors in meat tenderness. Trends Food Sci Technol 13:400-421. https://doi.org/10.1016/S0924 -2244(02)00188-7

Stadnik J, Kęska P (2015) Meat and fermented meat products as a source of bioactive peptides. Acta Sci Pol Technol Aliment 14:181-190. https://doi.org/10.17306/J.AFS.2015.3.19

Takeda $S$ et al (2017) Investigation of lactic acid bacterial strains for meat fermentation and the product's antioxidant and angiotensinI-converting-enzyme inhibitory activities. Anim Sci J 88:507516. https://doi.org/10.1111/asj.12673

Tavares T, del Mar Contreras M, Amorim M, Pintado M, Recio I, Malcata FX (2011) Novel whey-derived peptides with inhibitory effect against angiotensin-converting enzyme: in vitro effect and stability to gastrointestinal enzymes. Peptides 32:1013-1019. https://doi.org/10.1016/j.peptides.2011.02.005

Toopcham T, Mes JJ, Wichers HJ, Roytrakul S, Yongsawatdigul J (2017) Bioavailability of angiotensin I-converting enzyme (ACE) inhibitory peptides derived from Virgibacillus halodenitrificans SK1-3-7 proteinases hydrolyzed tilapia muscle proteins. Food Chem 220:190-197

UniProt Consortium (2017) UniProt: the universal protein knowledgebase. Nucleic Acids Res 45(D1):D158-D169. https://doi. org/10.1093/nar/gkw1099

Vermeirssen V, Van Camp J, Verstraete W (2004) Bioavailability of angiotensin I converting enzyme inhibitory peptides. Br J Nutr 92:357-366

Wójciak KM, Dolatowski ZJ, Kołożyn-Krajewska D, Trząskowska M (2012) The effect of the Lactobacillus casei LOCK 0900 probiotic strain on the quality of dry-fermented sausage during chilling storage. J Food Qual 35:353-365. https://doi.org/10.111 $1 /$ j.1745-4557.2012.00458.x

Wu J, Ding X (2002) Characterization of inhibition and stability of soy-protein-derived angiotensin I-converting enzyme inhibitory peptides. Food Res Int 35:367-375. https://doi.org/10.1016/S0963 -9969(01)00131-4

Wu J, Liao W, Udenigwe CC (2017) Revisiting the mechanisms of ACE inhibitory peptides from food proteins. Trends Food Sci Technol 69:214-219. https://doi.org/10.1016/j.tifs.2017.07.011

Yamamoto N (1997) Antihypertensive peptides derived from food proteins. Pept Sci 43:129-134. https://doi.org/10.1002/(SICI)10970282(1997)43:2\%3C129::AID-BIP5\%3E3.0.CO;2-X

Zuo QX, Zhang WG, Xing LJ, Zheng JX, Zhou GH (2017) Stability of angiotensin I-converting enzyme inhibitory activity of peptides extracted from dry-cured Jinhua ham. J Food Nutr Res 5:301-308. https://doi.org/10.12691/jfnr-5-5-3 